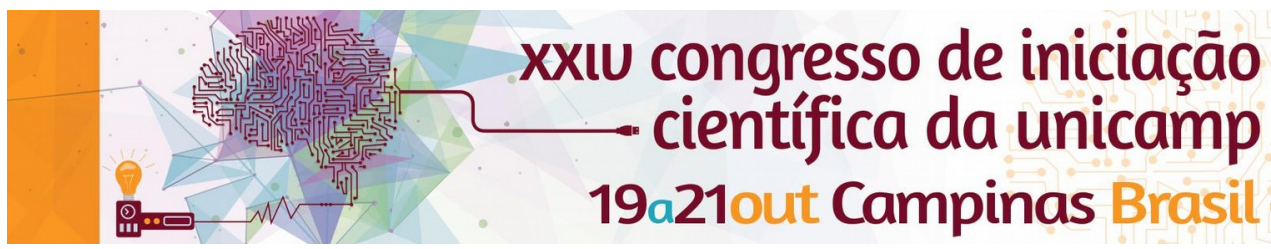

\title{
Estrutura de Produção da Microrregião de Limeira (SP) com Base na Pesquisa Industrial Anual (Brasil, São Paulo, Limeira)
}

\author{
Francisco Martellini*, Carlos R. Etulain (orientador)
}

\section{Resumo}

O trabalho busca conhecer as principais variáveis para a elaboração da análise econômica que avalia o desempenho da economia local e regional, concentrando-se no estudo da Estrutura de Produção da MRL, especialmente a partir da Pesquisa Industrial Anual (PIA) e da Relação Anual de Informações Sociais (RAIS), com período de cobertura de 2000 a 2014, com o objetivo de subsidiar análises sociais e econômicas mais gerais.

\section{Palavras-chave:}

Economia Regional, Análise Setorial da Indústria, Estrutura Econômica Regional

\section{Introdução}

O foco do projeto se concentra na estrutura de produção da MRL, contribuindo com a atualização da base de dados de pesquisa econômica feita pelo Laboratório de Economia e Gestão (LEG) da FCA/UNICAMP, utilizando principalmente a PIA, no período de 2000 a 2014, mas também outras bases de dados como a RAIS e o Censo 2010, para descrever a estrutura econômica, vocação local, setores predominantes e as possibilidades de desempenho da MRL.

\section{Resultados e Discussão}

O trabalho foi elaborado a partir de matrizes regionais de dados econômicos para o período, de 2000 a 2014, com os dados expandidos para 2015 quando possível.

Tabela 1: PIB e Participação no PIB.

\begin{tabular}{lcccc} 
Municípios & $\begin{array}{c}\text { PIB } \\
\text { (mil. R\$) }\end{array}$ & $\begin{array}{c}\text { Part. } \\
\text { Agro. } \\
\text { (\%) }\end{array}$ & $\begin{array}{c}\text { Part. } \\
\text { Ind. } \\
\text { (\%) }\end{array}$ & $\begin{array}{c}\text { Part. } \\
\text { Serv. } \\
\text { (\%) }\end{array}$ \\
\hline Araras & 2987,2 & 2,79 & 21,3 & 75,91 \\
Conchal & 456,87 & 9,1 & 30,99 & 59,91 \\
Cordeirópolis & 1892,97 & 1,88 & 21,86 & 76,26 \\
Iracemápolis & 488,85 & 4,49 & 42,49 & 53,02 \\
Leme & 1736,04 & 3,96 & 27,38 & 68,66 \\
Limeira & 7718,28 & 1,25 & 34,42 & 64,33 \\
S. Cruz da Conceição & 85,9 & 27,99 & 15,44 & 56,57 \\
Santa Gertrudes & 491,67 & 1,85 & 43,46 & 54,7
\end{tabular}

Fonte: Fundação Seade

Tabela 2: Emprego e salário médio em Limeira.

\begin{tabular}{lccc}
\hline Setor & Estabel. & Empreg. & $\begin{array}{c}\text { Salário } \\
\text { Médio }\end{array}$ \\
\hline Comércio & 6224 & 5,94 & 1473 \\
Serviços e Adm. Pública & 4822 & 11,98 & 1752 \\
Ind. de Transformação & 2527 & 27,63 & 2396 \\
Agropec. e Ind. Ext. Mineral & 755 & 10,56 & 997 \\
Construção Civil & 926 & 5,25 & 1845 \\
Total & 15254 & 11,63 & 1699 \\
\hline
\end{tabular}

Fonte: RAIS, 2012.

Foi elaborada uma matriz contendo 9 variáveis de entrada para os 645 municípios do estado de São Paulo. A discussão realizada consistiu em conferir a participação dos setores de atividade em importância relativa para a MRL, outras microrregiões e o Estado.

\section{Conclusão}

Os dados mostram que o maior PIB corresponde a cidade de Limeira, uma tendência que se mostrou estável ao longo do tempo até o ano de 2012. Mesmo que o setor de serviços apresente maior participação no $\mathrm{PIB}$, a indústria também apresenta valores relevantes, mas com uma tendência de queda ao longo do período analisado.

A indústria ganha destaque na MRL como resultado da presença de grandes empresas que utilizam matériaprima para seus produtos e que são responsáveis por boa parte dos empregos. A cidade de Limeira que é representativa de toda a MRL abriga 7312 empresas em todos os setores de atividade (RAIS, 2012), $40 \%$ das empresas do setor de comércio e outros serviços empregam, cada uma, menos de 5 funcionários, enquanto que $4 \%$ das firmas da indústria empregam em média 50 funcionários, as indústrias de porte médio são responsáveis por 6.000 postos de trabalho e as grandes por 12.000 vagas. As grandes empresas da indústria de transformação são importantes também quando se considera o valor do salário médio pago, que é maior do que o correspondente às empresas de mesmo tamanho em outros setores. Em 2012 as empresas com mais de 100 funcionários remuneraram em média $R \$ 1.500,00$ por mês (RAIS, 2012). Entre 2006 e 2012, comércio, serviços e administração públicas em conjunto apresentaram aumento substancial tanto nas quantidades de estabelecimentos - com aumento de $43,9 \%$ no número de estabelecimento, no volume de emprego - com aumento de $44,4 \%$ dos empregos, e na média salarial - com aumento médio de $120,9 \%$ (RAIS, 2012).

ETULAIN, C.R. (org.) Perfil Econômico e Industrial da Microrregião de Limeira, LEG,FCA/Unicamp, Relatório, 2012. pdf.

et al. "Perfil econômico da Microrregião da Limeira", p. 33 62.IN:BAENINGER, R; PERES, R.G; D'ANTONA, A.O; ETULAIN, C.R. Por Dentro doEstado de São Paulo: Região de Limeira. São Paulo: Traço Publicações e Desing, 2012. 104 p 